\title{
Response Of Maize Varieties To Sowing Dates In Inner Terai Region, Dang, Nepal
}

\author{
Pukar Khanal' ${ }^{1}$ Rupak Karn'*, Pratibha Budhathoki Chhetri', Samita Karki², Shrawan Kumar Sah¹
}

${ }^{1}$ Agriculture and Forestry University, Rampur, Chitwan, Nepal

${ }^{2}$ Institute of Agriculture and Animal Sciences, Mahendra Ratna Multiple Campus (MRMC), Ilam, Nepal

*Corresponding Author email: coolrupak99@gmail.com

\section{Doi: 10.2478/mjhr-2019-0011}

\begin{abstract}
:
Sowing dates and varieties affect the productivity of maize. A field experiment was conducted to find out the response of maize hybrids to sowing dates on growth and productivity of maize in spring season at Lamahi, Dang in 2019. The experiment was laid out in two factor factorial Randomized Complete Block Design with four replications. The treatment consisted of combination of three different sowing dates (February 1, February12 and February 23 ) and two maize varieties (Arun-2 i.e. OPV and hybrid Bioseed-9220).The result revealed that earlier planting on February 1 produced the highest yield (8265 Kg ha1 ) which was significantly superior than latter planting of February $12(6099 \mathrm{~kg}$ ha-1)and February 23 (5934 kg ha-1).The higher yield in earlier planting was due to significantly higher no of kernel per ear, non-significant but higher number of cob per unit area, thousand grain weight. Similarly, Bioseed 9220 produced higher yield (7798 kg ha-1) compared to Arun-2 (5,734 kg ha-1). The higher yield of hybrid Bioseed 9220 was because of higher number of cob per unit area harvested and more number of kernel per cob. Therefore, earlier planting with hybrid maize is recommended in spring season of Dang and locations with similar climatic conditions for higher productivity of maize.
\end{abstract}

Keywords: Maize, Sowing Dates, Variety, Yield

\subsection{Introduction:}

Maize is the third most important crop of the world. It is ranked as second most important crop after rice in Nepal. It is also referred as 'Miracle crop' or 'Queen of the cereals'. Nepal is a diversified country which consists various agro-ecological zone with potentiality of production of different agricultural crops with agriculture being profession for majority of the population to sustain their livelihood. Agriculture sector contributes $32.12 \%$ to the country's Gross Domestic Product [1]. Dang district is one of the advanced and developed Terai district of Mid-Western Development Region of Nepal. According to New Constitution of Nepal, 2072, Dang lies in Province no. 5 and it spreads from $82^{\circ} 02^{\prime}$ E to $82^{\circ} 54^{\prime} \mathrm{E}$ and $27^{\circ} 37^{\prime} \mathrm{N}$ to $28^{\circ} 29^{\prime} \mathrm{N}$ with an area coverage of 2,955 square kilometer (295500 hectare). Altitude wise, the district's topography ranges from a low of 213 meters (Bhanpur of Sishaniya VDC) from the sea level to 2058 meter (Arkhale of Hansipur VDC) comprising hill slopes, forest lands of different types, large and small valleys, doons, ravines, streams and rivers. The district can be divided into two big valleys (the northern is Dang Valley and the southern is Deukhuri Valley) and one small valley (Phulbari)

The global area of maize production is 19,71,85,936 ha with the production of 1,13,47,46,667 tons and productivity 5.75 t ha-1.Similarly Area of maize production in Nepal is 9,54,158 ha with the production of $25,55,874$ tons and productivity 2.67 tha- 1 .In Nepal, maize was introduced probably at the beginning of 17th century and it is grown throughout the year in Dang district. In the Dang district, the area under maize crop was 23,200 ha in the FY 2015, producing 46,168 ton of grains (which represents just 2.15\% of total annual maize production) with mean yield of $1.99 \mathrm{MT} / \mathrm{ha}$, which is low compared to national productivity $2.5 \mathrm{MT} / \mathrm{ha}$ [2]. This is largely due to inadequate nutrient supply and yearly flood disasters occurrence. Furthermore, in Dang district, most of the maize area is occupied by hybrid during various growing season especially for spring and winter with adequate irrigation system among commercial farmers. Government of Nepal has implemented Prime Minister Agriculture Modernization project for commercialization, mechanization and industrialization of agriculture sector at district/zone/state level as block/zone/super zone since 2016. Under PM-AMP, Dang district is the Superzone of maize production linking it to maize based industry for sustainable and self-reliant agriculture. Dang is the emerging production hub of maize through commercialization and mechanization, finally linking to industrialization with end markets potentiality of maize and maize product. In Nepal, maize production area is highest in Hills i.e. $73.78 \%$, followed by Terai i.e. $16.41 \%$ and mountain i.e. $9.79 \%$ but the yield (ton ha-1) is highest in terai i.e. 2.874 followed by 2.526 at hills and 2.235 at mountains. The farm level yield of maize (2.45 t/ha) is not satisfactory as compared to attainable yield (5.7 t/ha) in Nepal [3]. Maize contributes about $6.88 \%$ of the total agricultural GDP supplied to the nation [4].

Among the maize growing areas of Dang district, Satbariya is a high potential area for maize and maize seed production. However, people are unaware about the selection of high yielding maize varieties, its management practices and the proper plantation dates. Therefore, technological development regarding management and cultivation of the maize is necessary. Farmers also face several problems regarding irrigation, soil moisture status, sunshine hours, atmospheric condition are lagging behind the production and productivity of maize. Mainly in the area with limited irrigation facilities, water stress is a key factor that restricts the grain yield. It is known that the problems during plant growth for summer planting including, high temperature stress and insect pest infestation. The overall scenario of problems among maize growers indicates towards determining the suitable planting date to increase the maize yield and water use efficiency in rainfed farming system. So, shifting the planting time earlier than April may help to cope with problem of changing atmospheric condition, water use efficiency and also reduce the temperature and water stress during growth stages of maize. Early and late planting both influence the crop growth by changing the relationship between hydrothermal factors and growth stages [5]. All management aspect of growing maize crop, planting date is probably the most subject to variation because of the very great difference in weather condition at planting time between seasons and within the range of climate [6]. To reach this mission following specific objectives were considered.

- To determine the growth and productivity of spring maize at different sowing dates with different varieties in Dang

- To find out the interaction effect of sowing dates and varieties on growth and productivity of spring maize.

\subsection{Materials and methods}

\subsection{Site selection, Cropping history of experimental field}

The experiment was conducted at Lamahi 8, Satbariya in Dang District in Rapti zone of South western Nepal. Climate in the Dang valley is tropical to subtropical, characterized by monsoon rainfalls from June to September, which on average account for $85 \%$ of the total annual rainfall. The altitude of the site is 250 masl. Geographically longitude and latitude of the site is $82.3018^{\circ} \mathrm{East}$ and $27.9004^{\circ} \mathrm{North}$. The research area is located in western part about 280 $\mathrm{km}$ far from Kathmandu. Productive capability of the soil depends on its cropping history. The cropping history of the experim ental field prior to the experiment was rice followed by maize.

\subsection{Soil Characters}

A perusal of data on soil properties of experimental field revealed that the soil was neutral in reaction, low in nitrogen, medium in phosphorus and high in available potassium.

Table 1. Chemical properties of the soil of experimental field

\begin{tabular}{lcc}
\hline Parameter & Value & Rating \\
\hline Soil reaction (pH) & 7.4 & Neutral \\
Available total Nitrogen (\%) & 0.0545 & Low
\end{tabular}




\begin{tabular}{lcc}
\hline Available Phosphorus $\left(\mathrm{kg} \mathrm{ha}^{-1}\right)$ & 35.44 & Medium \\
Available Potassium $\left(\mathrm{kg} \mathrm{ha}^{-1}\right)$ & 200 & Medium \\
\hline Note: Based on rating chart by Khatri, Chhetri, 1991 & 200 \\
\hline
\end{tabular}

Note: Based on rating chart by Khatri, Chhetri, 1991

\subsection{Climatic conditions during the experiment}

Climate of Dang was characterized by three seasons: winter (Nov-Feb),spring (March-May) and summer (June-October). The average maximum and minimum temperature during cropping period were 34.189 and 22.67 degree Celsius respectively. The average rainfall during the cropping period was $201.5 \mathrm{~mm}$. The maximum relative humidity for the cropping period was $65 \%$ and minimum was $30 \%$.

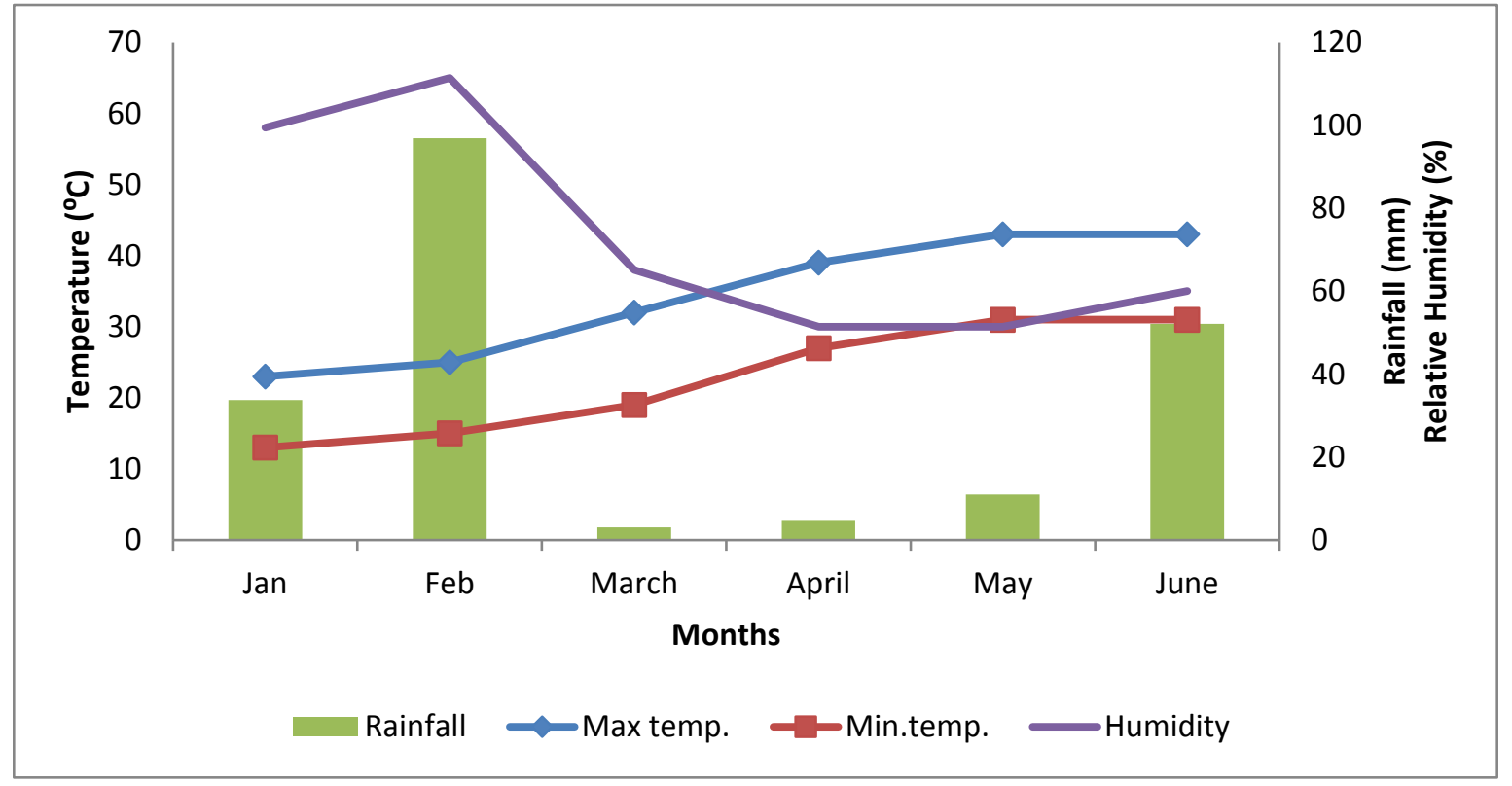

Figure 1: Weather conditions during the experimentation period at Lamahi 8 Satbariya, Dang from January to June, 2019

\subsection{Experimental details}

The experiment was conducted in two factor factorial RCBD with 4 replications and 6 treatments. Treatments consisted combination of following two factors ( 2 maize variety and 3 sowing dates). Maize was planted in five rows with eight plants in a row. Outer two rows were used as border line and remaining three rows were harvested for grain yield and other yield attributing parameters. Individual plot size was $3 \mathrm{~m} \times 2 \mathrm{~m}$ and seeds were sown at spacing of $60 \mathrm{~cm} \times 25 \mathrm{~cm}$ on 1 February, 12 February and 23 February, 2019 by Jab planter. The two varieties were Arun-2 and Bioseed 9220 . Observations on plant height, ear height, ear length, ear diameter, kernel rows/ear, kernels/ear, test weight, grain yield and soil pH was made. Detailed statistical analysis of data was performed by using GENSTAT fifteenth edition. Analysis of variance was performed with all data to confirm the validity of results.

\subsection{Results and Discussion}

\subsection{Effect of date of sowings and variety on phenology of spring maize}

Phenology was found non-significant due to date of sowings (Table 1). But it was comparatively higher at Feb 23 i.e. 3rd date of sowing than February 12 and February 1 . The duration to reach silking in spring maize was longer than that in summer maize because spring maize was staggered with the low initial temperature until mid April and had a slower early growth.

Table 2. Phenology of maize as influenced by Date of sowing and variety at Satbariya

\begin{tabular}{|c|c|c|c|}
\hline \multirow{2}{*}{ Treatment } & \multicolumn{3}{|c|}{ Phenology } \\
\hline & Days to tasseling & Days to silking & ASI \\
\hline Date of sowing & & & $S$ \\
\hline February 1 & 66 & 72.12 & 6.12 \\
\hline February 12 & 67.88 & 73.88 & 6 \\
\hline Februar 23 & 68.25 & 74.62 & 6.38 \\
\hline $\operatorname{SEm}( \pm)$ & 1.439 & 1.602 & 0.518 \\
\hline $\operatorname{LSD}(=0.05)$ & Ns & Ns & Ns \\
\hline \multicolumn{4}{|l|}{$\mathrm{CV}, \%$} \\
\hline \multicolumn{4}{|l|}{ Variety } \\
\hline Arun 2 & $57.83^{b}$ & $63.25^{\mathrm{b}}$ & $5.42^{\mathrm{b}}$ \\
\hline Bioseed 9220 & $76.92^{\mathrm{a}}$ & $83.83^{\mathrm{a}}$ & $6.92^{\mathrm{a}}$ \\
\hline $\operatorname{SEm}( \pm)$ & 1.175 & 1.308 & 0.423 \\
\hline $\operatorname{LSD}(=0.05)$ & 3.541 & 3.944 & 1.274 \\
\hline $\mathrm{CV}, \%$ & 6 & 6.2 & 23.7 \\
\hline Grand Mean & 67.38 & 73.54 & 6.17 \\
\hline
\end{tabular}


However, the maturity days, and specifically the seed fill durations were comparable to the range of 23-41 days as mentioned for maize [7]. It may be due to the hastened physiological processes with the increased temperature. Phenology was found significant due to variety. It was observed higher for Bioseed 9220 than Arun-2. The phenology under the similar conditions is genetically controlled traits. Since, Arun-2 is short duration variety ( 90 Days) and the Bioseed 9220 is medium duration hybrid variety (125 Days).

\subsection{Effect of date of sowings and variety on biometric character of spring maize}

Plant height was significantly higher at February 23 i.e. 3rd date of sowing than February 12 and February 1 at 45 DAP, 60 DAP and 75 DAP but at 90 DAP ,plant height was observed non-significantly higher in February 1 i.e. 1st date of sowing than February 12 and February 23(Table 2). In a study also stated that the temperatures encountered with early planting tend to reduce plant height mainly by decreasing internode length and less so by reducing leaf numbers [8]. Lower temperature encountered as well as lesser photosynthetic active radiation intercepted in 1st and 2nd sowings decreased the plant height upto 75 DAPS

Leaf area index was significantly higher at February 23 i.e. 3rd date of sowing than February 12 and February 1 at 30 DAP and 60 DAP and at 90 DAP it was significantly higher in February 1 (Table 6). In other study stated that planting maize too early and too late resulted in reduced leaf area index, leaf area, dry matter production and yield [9]. The mean temperature was highest at the time of third sowing which caused the higher vegetative growth of the third sown maize. Similarly, at 90 DAP, first date of sowing showed higher leaf area index because, the mean temperature at that time for 3rd sowing was also high supporting much vegetative growth. This data is in agreement with [9].

Table 3. Leaf area index of maize as influenced by Date of sowing and variety at Satbariya

\begin{tabular}{|c|c|c|c|}
\hline \multirow[t]{2}{*}{ Treatment } & \multicolumn{3}{|c|}{ Leaf Area Index } \\
\hline & 30 DAP & 60 DAP & $90 \mathrm{DAP}$ \\
\hline \multicolumn{4}{|l|}{ Date of sowing } \\
\hline February 1 & $0.114^{\mathrm{ab}}$ & $1.65^{\mathrm{b}}$ & $4.50^{\mathrm{a}}$ \\
\hline February12 & $0.074^{\mathrm{b}}$ & $1.54^{\mathrm{b}}$ & $2.41^{\mathrm{b}}$ \\
\hline February 23 & $0.177^{a}$ & $2.19^{\mathrm{a}}$ & $2.56^{\mathrm{b}}$ \\
\hline $\operatorname{SEm}( \pm)$ & 0.0212 & 0.174 & 0.278 \\
\hline $\operatorname{LSD}(=0.05)$ & 0.0640 & 0.523 & 0.839 \\
\hline \multicolumn{4}{|l|}{$\mathrm{CV}, \%$} \\
\hline \multicolumn{4}{|l|}{ Variety } \\
\hline Arun 2 & 0.132 & 1.82 & 3.16 \\
\hline Bioseed 9220 & 0.112 & 1.77 & 3.14 \\
\hline $\operatorname{SEm}( \pm)$ & 0.0173 & 0.142 & 0.227 \\
\hline $\operatorname{LSD}(=0.05)$ & Ns & Ns & Ns \\
\hline $\mathrm{CV}, \%$ & 49.3 & 27.4 & 25 \\
\hline Grand Mean & 0.122 & 1.79 & 3.15 \\
\hline
\end{tabular}

Plant height was significantly higher in Arun-2 than Bioseed 9220 whereas non-significantly but slightly higher leaf area index was observed in Arun-2 than Bioseed 9220 . The phenology under the similar conditions is genetically controlled traits. Since, Arun-2 is short duration variety ( 90 Days) and the Bioseed 9220 is medium duration hybrid variety (125 Days).

\subsection{Effect of date of sowings and variety on yield attributes and yield of spring maize}

Yield attributing characters i.e. no of ears per hectare, no of kernel per ear, thousand grain weight, sterility percentage, no of kernel per row, no of kernel row per ear, ear length and ear diameter were found non-significant to date of sowings whereas shelling percentage, bareness percentage were significantly influenced by date of sowings (Table 3) and (Table 4) where February 1 had significantly higher shelling percentage than 2nd and 3rd date of sowings. Similarly, February 1 has significantly lesser shelling percentage than 2 nd and 3rd date of sowings.

Table 4. Yield attributes of maize as influenced by Date of sowing and variety at Satbariya

\begin{tabular}{|c|c|c|c|c|c|c|c|}
\hline Treatment & Shelling \% & Sterility \% & No of kernel per row & No of kernel row per ear & Ear Length & Bareness (\%) & Ear diameter $(\mathrm{cm})$ \\
\hline \multicolumn{8}{|l|}{ Date of sowing } \\
\hline February 1 & $64.9^{\mathrm{a}}$ & 10.22 & 29.58 & 13.45 & 19.73 & $9.12^{\mathrm{b}}$ & 4.456 \\
\hline February 12 & $54.1^{\mathrm{b}}$ & 12.03 & 29.08 & 12.79 & 19.29 & $12.72^{\mathrm{ab}}$ & 4.477 \\
\hline February 23 & $64.3^{\mathrm{a}}$ & 11.41 & 25.50 & 13.33 & 19.57 & $13.08^{a}$ & 4.360 \\
\hline $\operatorname{SEm}( \pm)$ & 1.98 & 1.280 & 1.436 & 0.411 & 0.679 & 1.229 & 0.0786 \\
\hline $\operatorname{LSD}(=0.05)$ & 5.98 & Ns & Ns & Ns & Ns & Ns & Ns \\
\hline \multicolumn{8}{|l|}{$\mathrm{CV}, \%$} \\
\hline \multicolumn{8}{|l|}{ Variety } \\
\hline Arun 2 & 60.2 & 12.05 & 26.35 & $12.16^{\mathrm{b}}$ & $18.30^{\mathrm{b}}$ & 11.54 & $4.332^{\mathrm{b}}$ \\
\hline Bioseed 9220 & 62 & 10.40 & 29.76 & $14.22^{\mathrm{a}}$ & $20.76^{a}$ & 11.74 & $4.530^{\mathrm{a}}$ \\
\hline $\operatorname{SEm}( \pm)$ & 1.62 & 1.045 & 1.173 & 0.335 & 0.554 & 1.004 & 0.0642 \\
\hline $\operatorname{LSD}(=0.05)$ & Ns & Ns & Ns & 0.001 & 1.671 & Ns & 0.1935 \\
\hline $\mathrm{CV}, \%$ & 9.2 & 32.3 & 14.5 & 8.8 & 9.8 & 29.9 & 5 \\
\hline Grand Mean & 61.1 & 11.22 & 28.06 & 13.19 & 19.53 & 11.64 & 4.431 \\
\hline
\end{tabular}


Table 5. Yield and yield attributes of maize as influenced by Date of sowing and variety at Satbariya

\begin{tabular}{|c|c|c|c|c|}
\hline Treatment & No of ears per ha & No of kernel per ear & TGW(gram) & Yield $\left(\mathrm{kgha}^{-1}\right)$ \\
\hline \multicolumn{5}{|l|}{ Date of sowing } \\
\hline February 1 & 51618 & 383 & 260.5 & $8265^{a}$ \\
\hline February 12 & 49468 & 342 & 240.5 & $6099^{b}$ \\
\hline February 23 & 47089 & 332 & 273 & $5934^{b}$ \\
\hline $\operatorname{SEm}( \pm)$ & 2181.8 & 27.6 & 12.64 & 461.9 \\
\hline $\operatorname{LSD}(=0.05)$ & Ns & Ns & Ns & 1392.2 \\
\hline \multicolumn{5}{|l|}{$\mathrm{CV}, \%$} \\
\hline \multicolumn{5}{|l|}{ Variety } \\
\hline Arun 2 & 48598 & $305^{b}$ & 265.8 & $5734^{b}$ \\
\hline Bioseed 9220 & 50186 & $400^{\mathrm{a}}$ & 250.1 & $7798^{\mathrm{a}}$ \\
\hline $\operatorname{SEm}( \pm)$ & 1781.4 & 22.5 & 10.32 & 377.1 \\
\hline $\operatorname{LSD}(=0.05)$ & Ns & 67.8 & Ns & 1136.7 \\
\hline $\mathrm{CV}, \%$ & 12.5 & 22.1 & 13.9 & 19.3 \\
\hline Grand Mean & 49392 & 352 & 258 & 6766 \\
\hline
\end{tabular}

Yield was found significantly influenced by date of sowings where February 1 has significantly higher yield which is statically par with yield at February 23 i.e. 3rd date of sowing (Table 7). This is due to higher no of ears per hectare, higher no of kernel per ear, higher shelling percentage, higher no of kernel per row, higher no of kernel row per ear, higher ear length and lesser sterility percentage and lesser bareness percentage at first date of sowing i.e. February 1. This result is in agreement with the finding of who found out that early sowing in spring season has higher yield compared to delayed sowing [8]. Late planting causes crop to get more exposed to thermal condition during its active vegetative stage which results in more vegetative development thereby reducing dry matter accumulation and reduces grain yield ultimately. Delay in planting may also result less individual kernel mass leading to reduced yield. According to a study, Early and intermediate sowings tended to best utilize solar radiation and thus resulted high grain yield [7]. Also stated that delay in sowing decreases number of rows per ear, number of grains per row, number of grain per ear, grain weight and grain yield of maize.

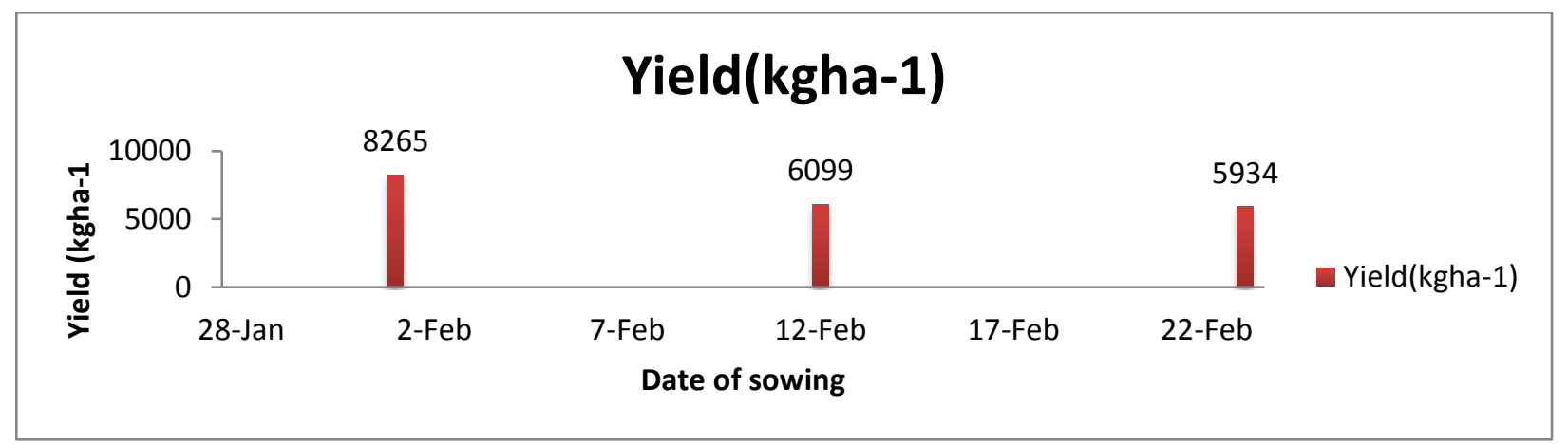

Figure 2. Grain yield as influenced by date of sowings at Lamahi, Dang, Nepal, 2019

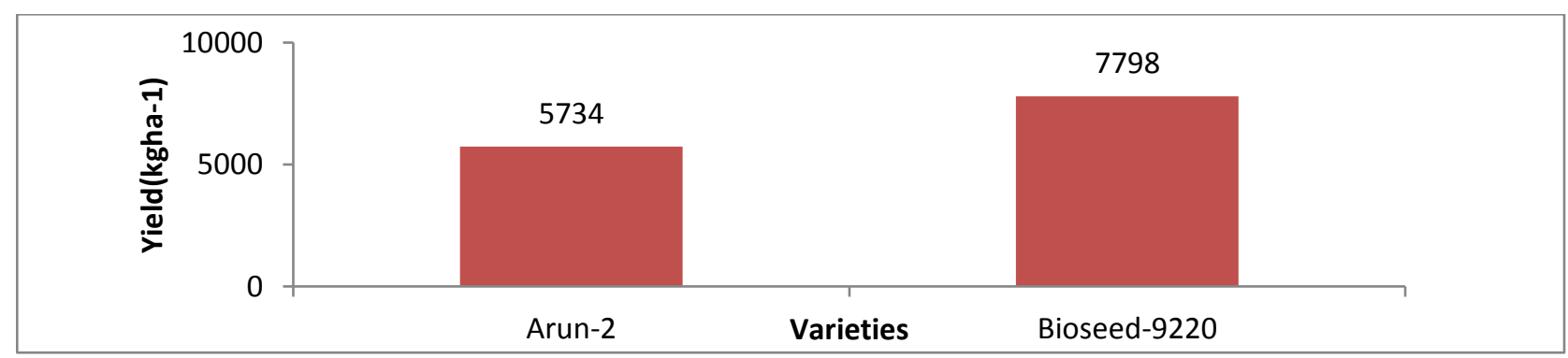

Figure 3. Grain yield as influenced by varieties at Lamahi, Dang, Nepal, 2019

Yield was significantly influenced by variety where Bioseed 9220 had significantly higher yield than Arun-2. Higher no of ears per hectare, no of kernel per ear, no of kernel per row, no of kernel row per ear, ear length and ear diameter was observed in Bioseed 9220 than Arun-2. Bioseed 9220 is long duration hybrid variety and Arun -2 is short duration OPV variety and Bioseed 9220 has longer grain filling period so the yield of Bioseed is higher. Some researchers stated that yield of hybrid maize is higher than open pollinated variety [3]. The result of the experiment showed that hybrid maize cultivar Bioseed 9220 outperformed OPV (Arun-2) in growth yield and yield attributes, this might be due to high leaf area at around 90 DAP where grain filling starts and it might have positively affected carbon assimilatory process [10]. This observation is consistent with.

\subsection{Conclusion}

Among the three different sowing dates of maize at Lamahi Dang,1st date of sowing i.e. February 1 has higher yield than 2nd date of sowing i.e. February 12 as well as 3 rd date of sowing i.e. February 23 ,so earlier planting in spring maize is best than delayed sowing. Similarly hybrid maize Bioseed 9220 has higher yield than open pollinated variety Arun-2 so hybrid maize in spring season is best than OPV.

\section{References}

[1] A.M. Al-Darby, and B. Lowery, "Seed Zone Soil Temperature and Early Corn Growth with Three Conservation Tillage Systems 1", Soil Science Society of America Journal, Vol. 51(3), 768-774, 19, 1987.

[2] Egli, and B. Dennis, "Seed Biology and Yield of Grain Crops", Plant and Soil Sciences Faculty Book Gallery, 5, 2017. 
[3] S. Ghimire, D.P. Sherchan, P. Andersen, C. Pokhrel, S. Ghimire, and D. Khanal, "Effect of Variety and Practice of Cultivation on Yield of Spring Maize in Terai of Nepal", Agrotechnol, 5(144), 2, 2016.

[4] MOAD. "Statistical information on nepalese agriculture. Singhdurbar, kathmandu", Nepal: Government of Nepal, Ministry of Agricultural Development, Agribussiness Promotion and Statistics Division, 2014.

[5] MOAD. "Statistical information on nepalese agriculture. Singhdurbar, kathmandu", Nepal: Government of Nepal, Ministry of Agricultural Development, Agribussiness Promotion and Statistics Division, 2015.

[6] M. Otegui, M. Nicolini, R. Ruiz, and P. Dodds, "Sowing date effects on grain yield components for different maize genotypes", Agronomy Journal, 29-33, 1995.

[7] U. Shrestha, L.P. Amgain, T.B. Karki, K.R. Dahal, and J. Shrestha, "Effect of Sowing Dates and Maize Cultivars in Growth and Yield of Maize along with their Agro-climatic Indices in Nawalparasi, Nepal", Journal of AgriSearch, 57-62, 2016.

[8] S.P. Swanson, and W.W. Wilhelm, "Planting date and residue rate effects on growth, partitioning, and yield of corn," Agronomy Journal, Vol. 88(2), 205210, 1996.

[9] M. Tollenaar, and E.A. Lee, "Dissection of physiological processes underlying grain yield in maize by examining genetic improvement and heterosis", Maydica, 51(2), 399, 2006.

[10] D. Wang, G. Li, Y. Mo, M. Cai, and X. Bian, "Effect of planting date on accumulated temperature and maize growth under mulched drip irrigation in a middle-latitude area with frequent chilling injury", Sustainability, Vol. 9(9), 1500, 2017. 